3.Государственная программа "Стратегия развития информационного общества Российской Федерации на 2017-2030 годы". URL: http://www.kremlin.ru/acts/bank/41919.

4.Государственная программа "Цифровая экономика Российской Федерации". URL: http://static.governme nt.ru/media/files/9gFM4FHj4PsB7915v7yLVuPgu4bvR7M0.pdf.

5.Алтухов П. Л., Мавлютова Г. А., Ножкина Е.Б. Устойчивое развитие цифровой экономики как элемент обеспечения национальной безопасности Российской Федерации // Экономическая безопасность и качество. 2018. № 1 (30). С. 19-24

\title{
DIGITALIZATION OF MODERN LIFE: SOCIAL BARRIERS AND CONTRADICTIONS
}

\author{
(C) 2020 Vyushkina Darya Dmitrievna \\ Student \\ Samara State University of Economics \\ E-mail: d.vyushkina94@mail.ru
}

Keywords: digitalization, public consciousness, digital technologies, culture, education, spheres of life of the population.

The article is devoted to the analysis of digitalization of modern life. This article discusses the contradictions of this process, its consequences. The article considers how digital technologies are changing the life of a person and society as a whole.

УДК 314.5

Код РИНЦ 04. 00.00

\section{МОРАЛЬНО-НРАВСТВЕННОЕ ОТНОШЕНИЕ К БРАЧНОМУ ДОГОВОРУ В РОССИИ С 1995 ГОДА ПО НАСТОЯЩЕЕ ВРЕМЯ}

\author{
(c) 2020 Глотова Ангелина Витальевна* \\ студент \\ Самарский государственный экономический университет \\ E-mail: awesome.glotova@yandex.ru
}

\begin{abstract}
Ключевые слова: брачный договор, брак, развод, семейный кодекс РФ, супруги, поколение, респондент.

В статье поднимается проблема морально-нравственного отношения граждан России к брачному договору, выявляется тенденция изменения данного отношения от старшего поколения к молодому. Автор формулирует тезис о том, что молодое поколение относится к брачному договору более лояльно, чем старшее, и для его подтверждения проводит опрос на тему: "Брачный договор: за или против".
\end{abstract}

\footnotetext{
* Научный руководитель - Чеджемов Герман Асланбекович, старший преподаватель.
} 
Ситуация с браками и разводами в России по данным Росстат на сегодняшний день складывается не самым хорошим образом. На 2016 год число заключенных браков составляет 985836, а число разводов - 608336(в среднем на 2 брака приходится 1 развод). По статистике средний возраст вступления в брак в Российской Федерации составляет 2035 лет. ${ }^{1}$

В юридическом понимании брак - юридически оформленный, свободный и добровольный союз мужчины и женщины, имеющий целью создание семьи, порождающий ряд личных и имущественных обязанностей. Брак может быть прекращен путем его расторжения по заявлению одного или обоих супругов(развод), а также по заявлению опекуна супруга, признанного судом недееспособным. ${ }^{2}$ Брак прошел очень длительный путь эволюции. Менялось общество и вместе с ним менялось отношение к браку. ${ }^{3}$

Высокая частота разводов в Российской Федерации обуславливает актуальность использования супругами такого правового института, как брачный договор.

Брачный договор (Ст. 40 СК РФ) - соглашение лиц, вступающих в брак, или соглашение супругов, определяющее имущественные права и обязанности супругов в браке и (или) в случае его расторжения. Этим договором супруги вправе изменить установленный законом режим совместной собственности, установить режим совместной, долевой или раздельной собственности на все имущество супругов, на его отдельные виды или на имущество каждого из супругов, а также определить в нем свои права и обязанности по взаимному содержанию, способы участия в доходах друг друга, порядок несения каждым из них семейных расходов; определить имущество, которое будет передано каждому из супругов в случае расторжения брака, а также включить в брачный договор любые иные положения, касающиеся имущественных отношений супругов. ${ }^{2}$

Углубляясь в историю данного явления, можно выделить следующее: до революции 1917 года понятия "брачный договор" не существовало, так как религиозное мировоззрение диктовало, что браки заключались исключительно "на небесах", естественно, при непосредственном участии церкви; в советский период по вполне понятным причинам(жесткая советская идеология) никаких деловых соглашений супруги не оформляли, и до недавнего времени отношения супругов регулировались Кодексом о браке и семье РСФСР 1969 года, предшественником Семейного кодекса 1995 года. Семейный кодекс Российской Федерации не только устранил те недостатки, которые содержались в РСФСР, а также ввел в российскую систему права ранее неизвестные правовые институты и отдельные нормы, но и сохранил отдельные принципы и нормы, которые были положительно проверены временем.

Но в нашем государстве сохраняется малая распространенность брачного договора, которая во многом связана со следующими причинами:

- Низкий процент среднего и высшего класса среди населения. Люди убеждены в том, что для заключения данного рода документов необходимо иметь как минимум доход выше среднего. Тем не менее брачный договор предназначен не только для хорошо обеспеченных граждан, но и для тех, кто не хочет тратить время и собственное здоровье при делении даже незначительного имущества.

- Недостаточно высокий уровень правовой и социальной культуры. Из-за недостаточно осведомленности и некорректной трактовки население неправильно воспринимает контракт и негативно относится к его заключению. 
- Моральная составляющая.

- Менталитет и влияние прошлого. В Советском Союзе большую часть времени не было частной собственности и делить было нечего. Кроме того, в основном браки заключались по любви, слово "развод" считалось осудительным. ${ }^{4}$

Данные причины были связаны в основном с экономическим содержанием этого документа, что вызывает неоднозначную морально-нравственную оценку, которая, в основном, связана с проявлением меркантильности одного из супругов. Но за границей брачный договор получает широкое распространение и не имеет такой негативной окраски. Это происходит за счет того, что в отличие от других государств, в России данный правовой документ регламентирует исключительно имущественные отношения супругов, не касаясь личных неимущественных, как это принято во многих других государствах. Например, в Германии и Франции супруги в своем договоре могут предусмотреть наступление неблагоприятных (в основном имущественных) последствий, в случае измены или злоупотребления алкоголя одним из супругов. Такой санкцией может быть изъятие пострадавшей стороной какого-либо ценного имущества у другой стороны (автомобиль, драгоценные металлы и т.д.). В США в контракте могут быть прописаны любы формы совместной жизни супругов, условия содержания и воспитания детей.

Но экономическое содержание брачного контракта имеет свои плюсы. Как говорилось ранее, в России на 2016 год на 2 брака приходится 1 развод. Прописанные в брачном договоре пункты об разделении доходов, имущества и т.д. могут значительно облегчить бракоразводный процесс. Если же в 90-е года 20 века и в начале 2000-х годов процент брачных контрактов составлял 2-3 \% от вступивших в брак, то начиная с 2015 года (6\%) эта цифра неуклонно растет. Обусловлен этот рост повышением правовой грамотности у граждан РФ, смена поколения "социалистических" взрослых на поколение "либеральных" молодых, которые относятся к заключению брачного договора более лояльно, чем взрослое поколение. Молодые люди, чаще всего, вступают в брак, имея личное имущество (квартиру, машину, бизнес и т.д.) или же стабильный заработок, поэтому они стремятся ограничить участие друг друга в своих доходах. Еще одной причиной заключения данного договора может служить повторный брак - если в предыдущем браке индивид имел проблемы с делением имущества, он стремится обезопасить себя от повторного разбирательства. В массовом сознании идет процесс размывания нравственных норм, характерных для русской культуры. Все более распространяются прагматизм, ориентация на личную выгоду. ${ }^{5}$

Поэтому, автором был выдвинут тезис о том, что молодое поколение относится к заключению брачного контракта более толерантно, чем старшее. Для его подтверждения, был проведен социологический опрос на тему: "Брачный договор: За или Против". Респондентам мужского и женского пола в двух возрастных категориях (18-34 и 35+) было предложено ответить на следующие вопросы:

- Случалось, ли вам слышать о брачном договоре?

- Можете ли вы дать определение брачному договору?

- Смогли бы вы предложить своему супругу(е) заключить брачный контракт?

- Как бы Вы отнеслись к предложению любимого(ой) заключить брачный контракт?

- Считаете ли вы, что предложение супруга(и) о заключении брачного контракта является признаком недоверия? 
- Как вы считаете, по какой причине супруги могут заключить брачный договор?

В данном опросе приняло участие 118 респондентов, 59,3\% женщин(66) и 40,7\% мужчин(48) из них 62 человека в возрасте 18-35 лет и 52 человека старше 35.

Девушки в возрасте 18-35 лет (40) в основной своей массе - 95\% (38) - смогли дать определение брачному контракту и 5\% (2) слышали о нем, но не имеют об этом представления. Половина опрошенных готова предложить своему супругу заключить брачный договор, 45\%(18) допускают такую возможность, и только 5\% (2) никогда бы не пошли на это. Четверть опрошенных (10) положительно отнеслась к предложению супруга заключить брачный договор, 50\%(20) скорее положительно, чем отрицательно, 20\%(8) скорее отрицательно, чем положительно и 5\%(2) предпочли бы прекратить отношения с таким человеком. Предложение супруга о заключении брачного контракта признаком недоверия посчитали всего лишь 5 \%(2), высказались неоднозначно 45\%(18), и были против 50\% (20). По мнению респондентов, причиной супругов заключить брачный контракт является: жизненные принципы 25\%(10), степень доверия между супругами (10)25\%, материальное положение $40 \%$ (16), другое 10\%(4).

Все опрошенные мужчины в возрасте 18-35 лет (22) дали определение брачному договору. готовы предложить своей супруге заключить брачный договор 55\%(12), 27\%(6) допускают такую возможность, и 17,5\% (4) никогда бы не пошли на это. К предложению супруги заключить брачный договор $36 \%$ опрошенных (8) отнеслись положительно, 18\%(4) скорее положительно, чем отрицательно, и 46\%(10) скорее отрицательно, чем положительно Предложение супруги о заключении брачного контракта признаком недоверия посчитали 45,5 \%(10), высказались неоднозначно 36,5\%(8), и были против 18\% (4). По мнению молодых людей, причиной супругов заключить брачный контракт является: жизненные принципы $27 \%(6)$, степень доверия между супругами (10) \%, материальное положение $40 \%$ (16), другое 10\%(4).

Женщины старше 35 лет (26) в 54\% (14) случаях смогли дать определение брачному контракту и 46\% (12) слышали о нем, но не имеют об этом представления. Почти половина женщин 46\%(12) готовы предложить своему супругу заключить брачный договор, 31,5\%(8) допускают такую возможность, и 23\% (6) никогда бы не пошли на это. Только 8\% опрошенных (2) положительно отнеслись к предложению супруга заключить брачный договор, 77\%(20) скорее положительно, чем отрицательно, и 15\%(4) скорее отрицательно, чем положительно. Предложение супруга о заключении брачного контракта признаком недоверия посчитали $23 \%(6)$, высказались неоднозначно 54\%(14), и были против 23\% (6). По мнению женщин, причиной супругов заключить брачный контракт является: жизненные принципы 38,5\%(10), степень доверия между супругами (4)15\%, материальное положение $38.5 \%$ (10), другое 8\%(2).

Мужчины старше 35 лет (26) в основной своей массе - 77\%(20) смогли сказать, что такое брачный договор и $23 \%$ (6) слышали о нем, но не имеют об этом представления. Лишь 23\%(6) смогли бы предложить своему супругу заключить брачный договор, 31\%(8) допускают такую возможность, 46\% (12) никогда бы не пошли на это. Положительно отнеслись к предложению супруги заключить брачный договор 15\% опрошенных мужчин (4), 8\%(2) - скорее положительно, чем отрицательно, 62\%(16) - скорее отрицательно, чем положительно, а 15\%(4) - предпочли прекратить отношения с таким человеком. Предложение супруга о заключении брачного контракта признаком недоверия посчитали 46 \%(12), 
высказались неоднозначно - 46\%(12), и были против лишь 8\% (2). По мнению респондентов, причиной супругов заключить брачный контракт является: жизненные принципы $23 \%(6)$, степень доверия между супругами - (10)39 \%, материальное положение - 31\% (8), другое - 7\%(2).

На основе этих результатов можно сделать следующие выводы:

- Самыми положительно настроенными к заключению брачного договора являются девушки в возрасте 18-35 лет. Более половины из них самостоятельно готовы предложить брачный договор супругу и положительно отнесутся к такому предложению от него. По мнению автора, это объясняется повышением трудоустройства женщин и расширением списка профессий, которыми они могут заниматься.

- Самыми отрицательно настроенными оказались мужчины старше 35 лет. Почти половина из них никогда бы не предложила своей супруге заключить брачный договор. 62 \% отнеслись бы к данному предложению от своей спутницы скорее отрицательно, чем положительно, а 15 \% и вовсе предпочли прекратить отношения после такой инициативы. Так же чуть больше половины мужчин старше 35 лет считают брачный договор новой фрормой брака по расчету. Данная негативная оценка у мужчин может быть вызвана главным образом тем, что, заключая брак во времена СССР, молодожены не имели "за плечами" никакого имущества и не думали о разводе, поэтому практически все имущество было совместно нажито в браке и должно было делиться пополам. Также в советское время государство тщательно стремилось не допускать разводов и сохранять семьи, что практически приводило к ненадобности института брачного контракта.

- Изменилось отношение мужчин к брачному договору. В отличии от старшего поколения 55\% опрошенных молодых людей готовы предложить такой контракт и $27 \%$ допускают эту возможность. Но при всем этом почти половина опрошенных скорее отрицательно, чем положительно, отнесется кпредложению супруги заключить брачный договор.

- Женщины старше 35 лет, как и девушки 18-35 лет, в половине случаев готовы заключить брачный договор и предложить его супругу. Данный факт объясняется тем, что в опросе принимали участие женщины, большинство из которых были или находятся в разводе.

- Основными причинами заключения брачных контрактов респондентами были выделены: материальное положение, степень доверия между супругами, жизненные принципы.

\footnotetext{
${ }^{1}$ Статистика браков и разводов по данным Росстат. https://rosinfostat.ru/braki-razvodi/

2 "Семейный кодекс Российской Федерации" от 29.12.1995 N 223-Ф3 (ред. от 06.02.2020). Глава 8. ДОГОВОРНЫЙ РЕЖИМ ИМУЩЕСТВА СУПРУГОВ

${ }^{3}$ Белянкина Е.О, Чеджемов Г.А. Отношение к браку: от древности до наших дней// Известия Института систем управления Самарского государственного экономического университета. Самара2017. №1(15). C.36

${ }^{4}$ Митусова Е. О. Брачный договор в России: "за" или "против"? // Вопросы студенческой науки Выпуск №5 (33), май 2019 С.69.

${ }^{5}$ Бондарев С.И, Чеджемов Г.А. Социальные проблемы города // Известия института систем управления Самарского государственного экономического университета-2011 №2(3). -С.16.
} 


\title{
MORAL ATTITUDE TO MARRIAGE CONTRACT IN RUSSIA FROM 1995 TO THE PRESENT
}

\author{
(c) 2020 Glotova Angelina Vital'yevna \\ Student \\ Samara State University of Economics \\ E-mail: awesome.glotova@yandex.ru
}

Keywords: marriage contract, marriage, divorce, family code of the Russian federation, spouses, generation, respondent.

This article raises the problem of the moral and ethical attitude of Russian citizens to a marriage contract, reveals a tendency to change this attitude from the older generation to the younger. The author puts the thesis that the younger generation is more loyal to the marriage contract than the older one, and to confirm it conducts a survey on the topic: "Marriage contract: For or Against".

УДК 316.36

Код РИНЦ 06.00.00

\section{ПРОДВИЖЕНИЕ ЗАКОНА ПРОТИВ ДОМАШНЕГО НАСИЛИЯ В СОЦИАЛЬНЫХ СЕТЯХ}

\author{
(c) 2020 Джигерова Кристина Эндриковна* \\ студент \\ Самарский государственный экономический университет \\ E-mail: dzhigerova.k@yandex.ru
}

Ключевые слова: принятие закона, закон, домашнее насилие, семейно-бытовое насилие, блогер, петиция, социальные сети.

Изучена история зарождения петиции о домашнем насилии в социальных сетях, а также выделена особая актуальность данной проблемы в современном обществе.

Что мы понимаем под фразой "домашнее насилие"? Обычно под этим понятием подразумеваются насильственные действия, которые совершаются внутри одной семьи. В феврале 2017 года в России был принят закон о декриминализации побоев. Таким образом, закон вывел семейно-бытовое насилие из-под действия уголовного законодательства с целью укрепления института брака. Через год в 2018 уполномоченный по правам человека в Российской Федерации Татьяна Москалькова заявила, что считает декриминализацию домашнего насилия ошибкой, однако глава Следственного комитета А.Бастрыкин раскритиковал данную позицию. Предполагалось, что соответствующий законопроект будет готов к внесению в Госдуму до 1 декабря 2019 года. Предложено оберегать защитными предписаниями жертв домашнего насилия в РФ, которые имеют судебный и внесудебный характеры.

* Научный руководитель - Чеджемов Герман Асланбекович, старший преподаватель. 